\title{
Review on Effect of Climate Change and Urbanization on Agriculture
}

\author{
Zakir Ababor ${ }^{1} \quad$ Mohammedsani Zakir ${ }^{2}$ \\ Ethiopian Institute of Agricultural Research; Jimma Agricultural Research Center, Jimma Ethiopia
}

\begin{abstract}
Climate is the primary important factor for agricultural production. The work topics concentrate possible physical effects of climatic change on agriculture, such as changes in crop and livestock yields as well as the economic consequences of these potential yield changes. In addition to this understanding of long-term changes in precipitation and temperature patterns is important in the detection and characterization of climate change. The role that climatic change has played in the pattern of urbanization in sub-Saharan African countries compared to the rest of the developing world and climatic changes represented by rainfall, has acted to change urbanization in sub-Saharan Africa. The cultivated land loss due to urbanization not only threatens food security in, but has also led to ecological system degradation to which close attention should be paid. In other hand climate change and urbanization have caused temporal changes in precipitation and temperature. Finally this paper reviews the effects of climate change and urbanization on agriculture. The main interests, concerning the role of human adaptations in responding to climate change, the impacts of climate change and urbanization, possible regional impacts to agricultural systems and potential changes in patterns of food production.
\end{abstract}

Keywords: Agriculture, climate change, global warming, impact, urbanization

DOI: $10.7176 / \mathrm{CER} / 11-5-04$

Publication date:June $30^{\text {th }} 2019$

\section{INTRODUCTION}

The term climate describes the overall long-term characteristics of the weather experienced at a place. The ecosystems, agriculture, livelihoods and settlements of a region are very dependent on its climate. Climate change refers to a change in the state of the climate that can be identified by changes in the mean and/or the variability of its properties and that persists for an extended period, typically decades or longer. Climate change may be due to natural internal processes or external forcing or persistent anthropogenic changes in the composition of the atmosphere or in land-use (IPCC, 2007b).

The Intergovernmental Panel on Climate Change (IPCC) predicts increases in the mean global temperature of up to $5.8^{\circ} \mathrm{C}$ by 2050 as well as more frequent ENSO (El Niño/La Niñ) events with climatic conditions expected to become generally more variable as a consequence of these global environmental changes (GEC) and increasing temperatures the life history traits of indigenous and invasive species may be impacted (IPCC, 2007). In addition to global warming caused by greenhouse gases the effects of changes in land use/land cover on climate are an important part of GEC (Pielke et al., 2002; Kalnay and Cai, 2003) which are unfortunately and frequently overlooked (Pielke, 2005) for example, land use changes have been linked to alteration in surface energy and water balance (Foley et al., 2005) changes in land surface temperatures (Oke, 1981; Zhou and Wang, 2011) and habitat degradation and loss of biodiversity (Sala et al., 2000) as a result, modifications in local conditions may have an important impact on ecosystems and ecosystem services, for example plant-insect interactions and ultimately on agricultural productivity GEC, including climate variability and changes in agricultural land use, will most likely have their severest effects on already vulnerable poor communities, particularly in the developing world (Hope, 2009; Muller et al., 2011).

Agriculture is one of the sectors most affected by ongoing climate change. The wide range of literature on this subject demonstrates that damages caused by climate change can be relevant to both cropping and livestock activities (IPCC, 1990; Adams et al., 1998). Climate change will have a significant effect on the rural landscape and the equilibrium of agrarian and forest ecosystems (Walker and Steffen, 1997; Bruijnzeel, 2004) in fact climate change can affect different agricultural dimensions, causing losses in productivity, profitability and employment. Food security is clearly threatened by climate change (Sanchez, 2000; Siwar et al., 2013) due to the instability of crop production, induced changes in markets, food prices and supply chain infrastructure. Moreover, because of the multiple socio-economic and bio-physical factors affecting food systems and consequently food security, the capacity to adapt food systems to reduce their vulnerability to climate change is not uniform from a spatial point of view (Gregory et al., 2005). Aydinalp and Cresser (2008) reported that agriculture sector besides its primary role in producing food and fibers, it also performs other functions, such as management of renewable natural resources, construction and protection of landscape, conservation of biodiversity and contribution to maintain socio-economic activities in marginal and rural areas. Climate change could affects also this multifunctional role of agriculture (Klein et al., 2013).

The term urbanization has been described as an inter-spectral phenomenon involving all aspects of the 
human society and economy (World Bank, 2000). Urbanization increased residential population, expansion of non-farm business and industry, increases the pressure on farmers and makes it more costly and difficult to farm in the traditional way. The issue is complicated by the fact that population and business industry growth often takes place in prime agricultural areas (Asamoah, 2010). Such land use conversion often reduces the most fertile land and impact on agricultural production and food security is often larger than the absolute amount of land involved (Francis et al., 2013).

\section{EFFECT OF CLIMATE CHANGE AND URBANIZATION ON AGRICULTURE}

\subsection{Climate}

The term climate describes the overall long-term characteristics of the weather while; ecosystems, agriculture, livelihoods and settlements of a region are very dependent on its climate. The climate, therefore, can be thought of as a long-term summary of weather conditions, taking account of the average conditions as well as the variability of these conditions. The Earth's climate has varied considerably in the past. Climate change refers to a change in the state of the climate that can be identified by changes in the mean and/or the variability of its properties and that persists for an extended period, typically decades or longer (IPCC, 2007b).

\subsubsection{Impact of climate change on agriculture}

Changes in temperature as well as rainfall patterns and the increase in $\mathrm{CO}_{2}$ levels projected to accompany climate change will have important effects on global agriculture especially in the tropical regions. It is expected that crop productivity will alter due to these changes in climate, weather events and changes in patterns of pests and diseases. The suitable land areas for cultivation of key staple crops could undergo geographic shifts in response to climate change (Aydinalp and Cresser, 2008). Temperature, precipitation, atmospheric $\mathrm{CO}_{2}$ content, incidence of extreme events and sea level rise are the main climate change related drivers which impact agricultural production. Briefly the main categories of agricultural productivity implications are Crops and forage productivity and production cost where temperature, precipitation, atmospheric carbon dioxide content and extreme events are likely to alter plant growth and harvestable yield through a mixture of climatic and $\mathrm{CO}_{2}$ fertilization effects as well as impacts on plant water demand (through temperature affects on respiration and evapo-transpiration as well as $\mathrm{CO}_{2}$ affects on water use efficiency). Extreme events also play a role for example where droughts and floods become more severe, agricultural losses would increase (Adams et al., 1998). In particular, soil moisture loss is determined by temperature and maintenance of a constant water supply given any temperature increases need to be offset by precipitation increases and/or expansions in applied irrigation water. Furthermore, microbial decomposition is stimulated by warmer temperatures so the availability of soil nutrients and organic matter which helps hold the soil moisture may be negatively affected by warmer temperature. Irrigation water supply will be influenced by changes in the volume of water supplied by precipitation as well as by temperature alterations effects on evaporation also changes in temperature regimes can alter the timing of snow melt based runoff and thus both the seasonality of available water supply and the needed size of impoundments holding water for summer supplies (Aydinalp and Cresser, 2008). Extreme events also play a role where, for example, some studies indicate that the hydrologic cycle will be intensified such that droughts and floods will become more severe in low to mid-latitude regions again altering water availability seasonally and the needs for impoundments (McCarl and Reilly, 1999; Jacobs et al., 2000) discuss these issues at more length. In addition to the direct effects of climate change on agriculture, for example, sea level rise can inundate or require mitigation efforts along low-lying coastal regions. Indirect effects may also arise from alterations in the growth rates, distribution of weeds, pests and pathogens, rates of soil erosion and degradation, and alterations in ozone levels or UV-radiation.

\subsubsection{Agriculture and climate}

Agricultural facilities contribute approximately $20 \%$ of the annual increase in anthropogenic greenhouse gas emissions (IPCC, 1996). This sector contributes to global warming through carbon dioxide $\left(\mathrm{CO}_{2}\right)$, methane $\left(\mathrm{CH}_{4}\right)$ and nitrous oxide $\left(\mathrm{N}_{2} \mathrm{O}\right)$ gases emissions. The greenhouse gases allow the transmission of light reaching the earth, they block the transmission of heat (infra-red radiation) trying to escape from the atmosphere, thus trapping the heat as in a greenhouse. $\mathrm{CH}_{4}$ has the highest global warming potential, which is about 300 times the potential of $\mathrm{CO}_{2}$ and about 20 times that of $\mathrm{N}_{2} \mathrm{O}$ (IPCC, 1996). The main gas sources are nitrogen fertilizers, flooded rice fields, soil management, land conversion, biomass burning and livestock production and associated manure anthropogenic management. The livestock industry accounts approximately from $5 \%$ to $10 \%$ of the overall contribution to global warming (IPCC, 1996).

\subsubsection{Carbon dioxide $\left(\mathrm{CO}_{2}\right)$}

Primarily, deforestation due to agricultural expansion and land speculation was caused a major source of carbon emissions. When natural vegetation is converted into agricultural land, a large proportion of the soil carbon can also be lost as plants and dead organic matter are removed. This event contributes approximately a third of the total $\mathrm{CO}_{2}$ emissions globally. Therefore, $\mathrm{CO}_{2}$ is also released during the burning of agricultural crop waste, for example, during the burning of cereal straw, sugarcane stubble and rice straw. In many countries, it is a common 
practice to burn large quantities of crop residue, which results killing of insects and other pests as well as disease causing organisms and neutralizes soil acidity. To less extent, $\mathrm{CO}_{2}$ is released from the fossil fuels used in agricultural production and from livestock production. Nowadays, high-intensity animal production has become the biggest consumer of fossil energy in modern agriculture (IPCC, 1996).

\subsubsection{Methane $\left(\mathrm{CH}_{4}\right)$}

Methane $\mathrm{CH}_{4}$ is the most significant greenhouse gas released within the agriculture sector. Most of the methane releases come from paddy fields $(91 \%)$ and less significantly from animal husbandry (7\%) and burning of agricultural wastes (2\%) (Figure 1). The quantification of rice paddy emissions has proven difficult as the emissions vary with the amount of land in cultivation, fertilizer use, water management, density of rice plants and other agricultural practices. Among too many Asian countries, China is a very large source of $\mathrm{CH}_{4} \mathrm{emissions}$ Livestock and associated manure management causes $16 \%$ of the total annual production of $\mathrm{CH}_{4}$. These emissions are a direct result of the ability of buffalo and cattle to utilize large amounts of fibrous grasses that cannot be used as human food or as feed for pigs and poultry. Buffalo and cattle contribute about $80 \%$ of the global $\mathrm{CH}_{4}$ emissions from domestic livestock annually (Aydinalp and Cresser, 2008).

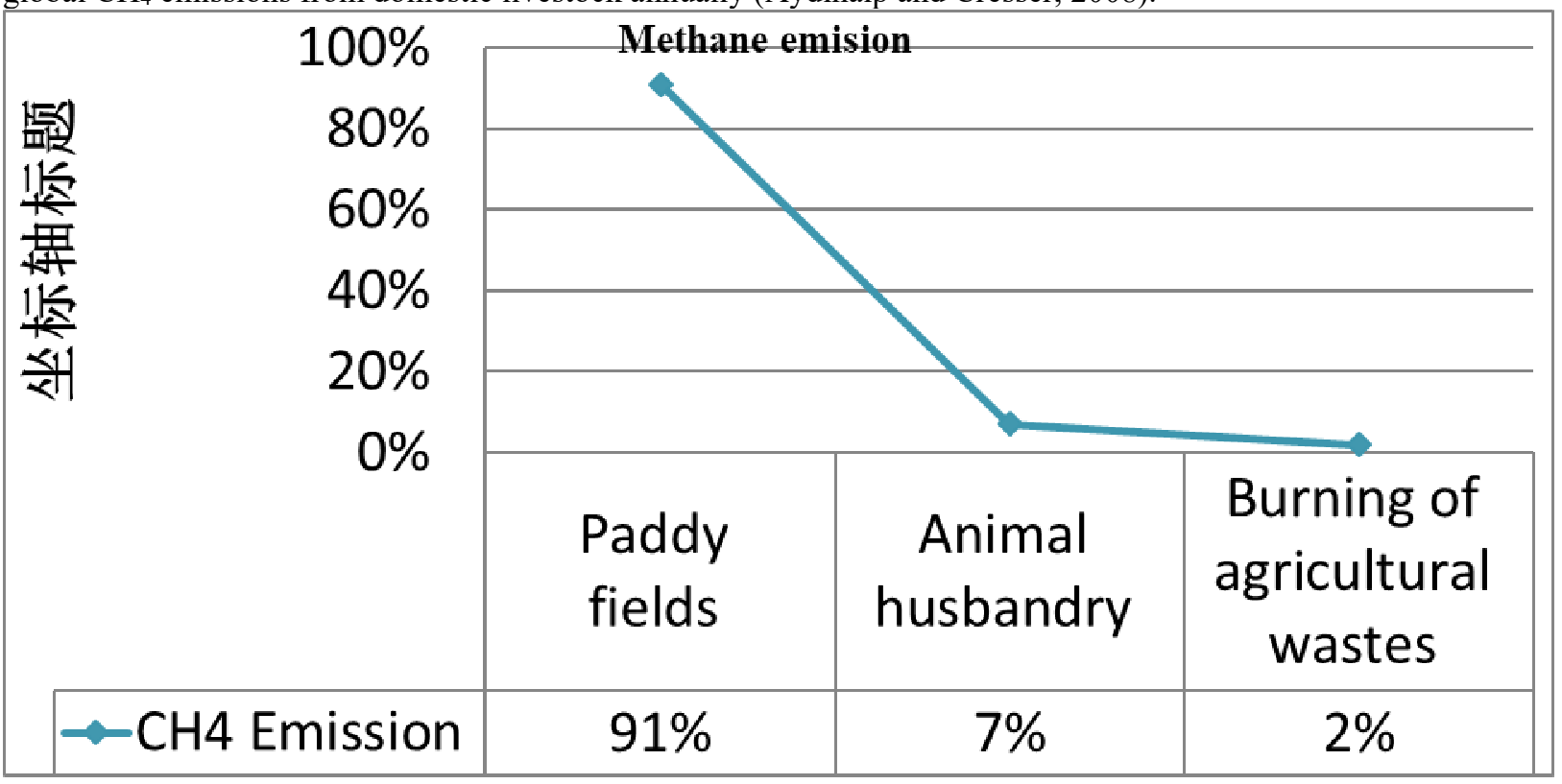

Figure 1: Methane emission variability

Source: Aydinalp and Cresser ,2008

2.1.2.3. Nitrous oxide $\left(\mathrm{N}_{2} \mathrm{O}\right)$

Most of the agriculture based $\mathrm{N}_{2} \mathrm{O}$ emissions come from nitrogen fertilizer usage, legume cropping and animal waste. Many farmers use nitrogen fertilizers on their fields to enhance crop growth. The crop takes up most of the nitrogen, but some of them leach into surrounding surface and ground waters and some of it enters the atmosphere. The nitrogen flux depends on the microbial activity in the soil. For example, wet rice absorbs only one-third of the nitrogen in the fertilizers, while upland crops about half. The rest of nitrogen is denitrified and diffused into the atmosphere, which is contributing to global warming. However, the amount of $\mathrm{N}_{2} \mathrm{O}$ emitted is much lower in volume than the amount of $\mathrm{CH}_{4}$ (Aydinalp and Cresser, 2008).

\subsubsection{Climate change could adversely influence agricultural production}

Geographical shifts and yield changes in agriculture, reduction in the quantity of water available for irrigation and loss of land through sea level rise and associated salinization. The yields of different crops and geographic limits may be altered by changes in soil moisture, temperature, precipitation, cloud cover, as well as increases in $\mathrm{CO}_{2}$ concentrations. The lowest rainfall and high temperature could reduce soil moisture in many areas, particularly in some tropical and mid-continental regions, reducing the available water for irrigation and impairing crop growth in non-irrigated areas of the many regions. The changes in soil properties such as erosion are a likely consequence of climate change for some soils in some climatic zones (WRI, 1998). The risk of losses due to weeds, insects and diseases is likely to increase. The range of many insects will change or expand and new combinations of diseases and pests may emerge as natural ecosystems respond to shifts in temperature and precipitation profiles. The effect of climate on pests may add to the effect of other factors such as the over use of pesticides and the loss of biodiversity, which already contribute to plant pest and disease outbreaks. Agriculture in low-lying coastal areas or adjacent to river deltas may be affected by a rise in sea level. Flooding will probably become a significant problem in some already flood-prone regions of Asia such as China, further south in Eastern Asia and similar environments in the world. Decreases in productivity are most likely in these regions, 
which are already flood-insecure. Climatic events, changes in rainfall and temperature could be damaging and costly to agriculture (WRI, 1998).

\subsection{Plant Yield and Climate Change}

Plant physiology has been greatly influenced by climate variability by several means. Environmental extremes and climate variability enhanced the chances of numerous stresses on plants (Thornton et al., 2014). Climate change affects crop production by means of direct, indirect, and socio-economic effects as described in Figure 2. Furthermore, climate change (drought, flood, high temperature, storm etc.) events are increased dramatically as reported by Food and Agriculture Organization (FAO) and as shown in Figure 3.

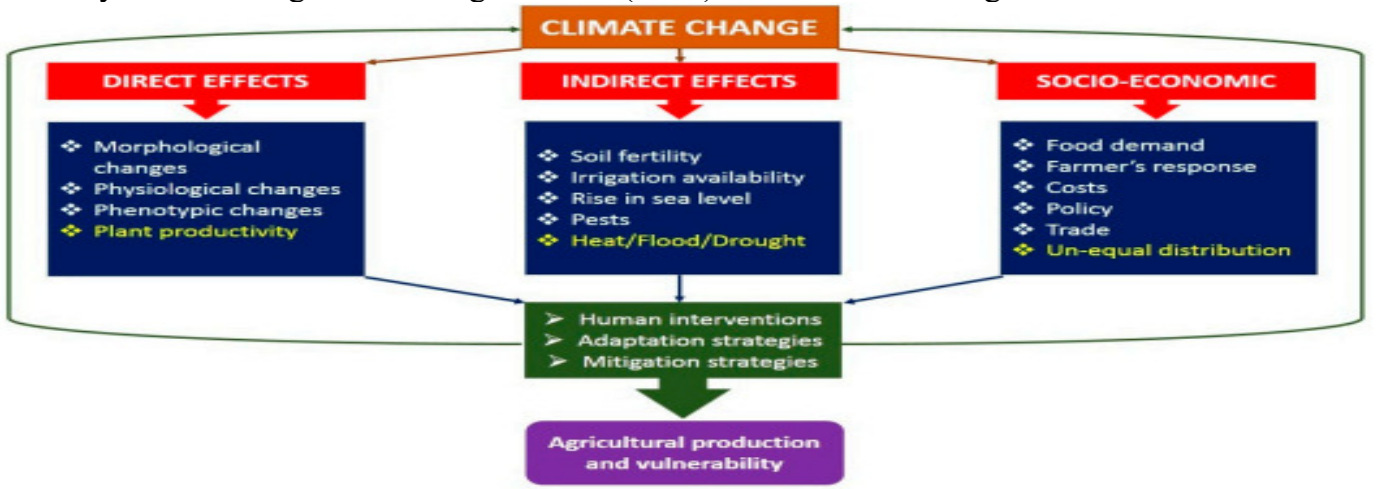

Figure 2:Direct, indirect and socio-economic effects of climate change on agricultural production

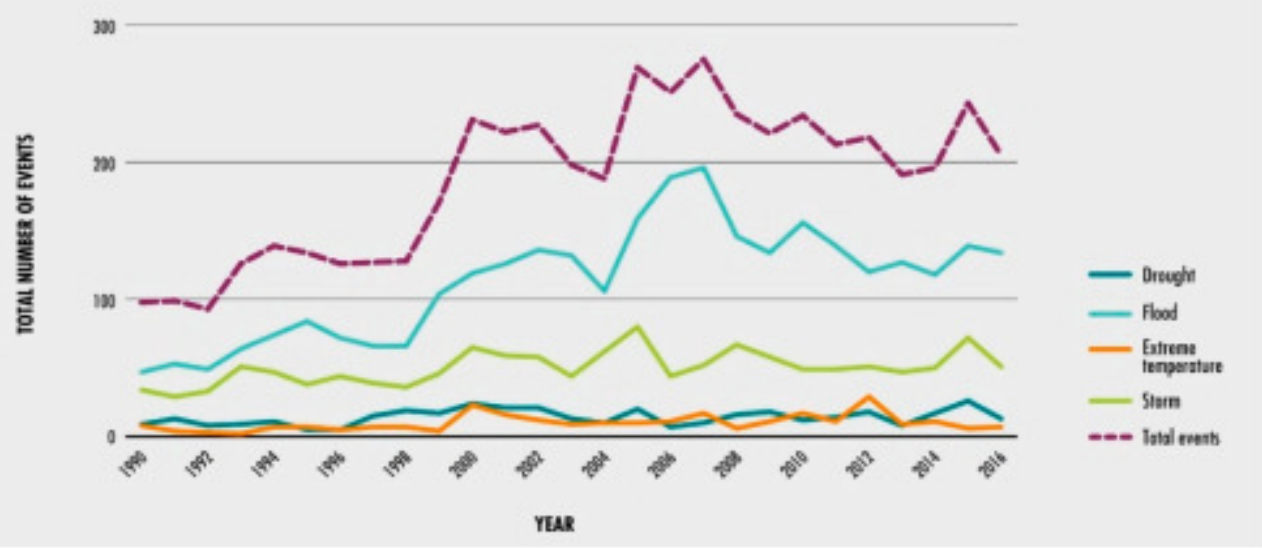

Figure 3: Increasing number of extreme climate-related events occurred during 1990-2016 Source: FAO based on data from Emergency Events Database (EM-DAT) (https://www.emdat.be/)

Boyer reported that the climate changes have reduced the crop yield up to $70 \%$ since 1982 . According to the study of FAO 2007 (http://www.fao.org/home/en/) all cultivated areas in the world are affected by climatic changes and only $3.5 \%$ of areas are safe from environmental limitations (Van, 2007). Whereas the outcomes of a biotic stresses on crop yield are hard to calculate accurately, it is believed that a biotic stresses have a substantial influence on crop production depending upon the extent of damage to the total area under cultivation. In future, the productivity of the major crops is estimated to drop in many countries of the world due to global warming, water shortage, and other environmental impacts (Bonan and Doney, 2018).

Wheat production is heavily affected by the temperature extremes due to climate change in many countries, and may reduce the crop yield by $6 \%$ for each ${ }^{\circ} \mathrm{C}$ rise in temperature (Asseng et al., 2015). Drought and high temperatures are key stress factors with high impact on cereal yields (Barnabás et al., 2008) and Rubisco, the central enzyme of photosynthesis, is disrupted if the temperature increases from $35^{\circ} \mathrm{C}$ and stops the photosynthetic process (Griffin et al.,2004). Due to climate change, water deficit and temperature extremes influence the reproductive phase of plant growth.

It was described that the flower initiation and inflorescence is badly affected by the water stress in cereals (Winkel et al., 1997). Similarly, if the temperature increases of about $30^{\circ} \mathrm{C}$ during floret development it can cause sterility in cereals (Saini and Aspinall et al.,1982). During the meiotic phase, wheat and rice suffered from the $35-75 \%$ reduction in grain set due to water deficit (Sheoran and Saini, 1997). In rice, drought stress greatly disturbs the process of fertilization and anthesis. Zhao et al. (2017) carried an experiment to analyze the climate 
change impact on major crop yields and showed considerable yield reductions of $6 \%, 3.2 \%, 3.1 \%$, and $7.4 \%$ in wheat, rice, soybean, and maize respectively. To tackle the climate change new discoveries in genomics are enabling climate-smart agriculture by developing climate resilient crops (Scheben et al., 2016).

\subsection{Crop Adaptation to Overall Extreme Climate Stresses}

With the increase of the Earth's temperature, the climate undergoes severe alterations and becomes a biotically stressful environmental changes are very damaging and pose various threats to naturally prevailing crop species (Espeland and Kettenring, 2018). Under field circumstances, drought and heat are the most predominant stresses and have a significant influence on plants (Pereira, 2016). These climatic problems severely distress plant development and yield, produce enormous responses, comprising molecular, biochemical, physiological and morphological modifications (Zandalinas et al., 2018). Overall, global warming and climate change both have some negative and positive effects on agricultural crops as well as on humans as explained in Figure 4.

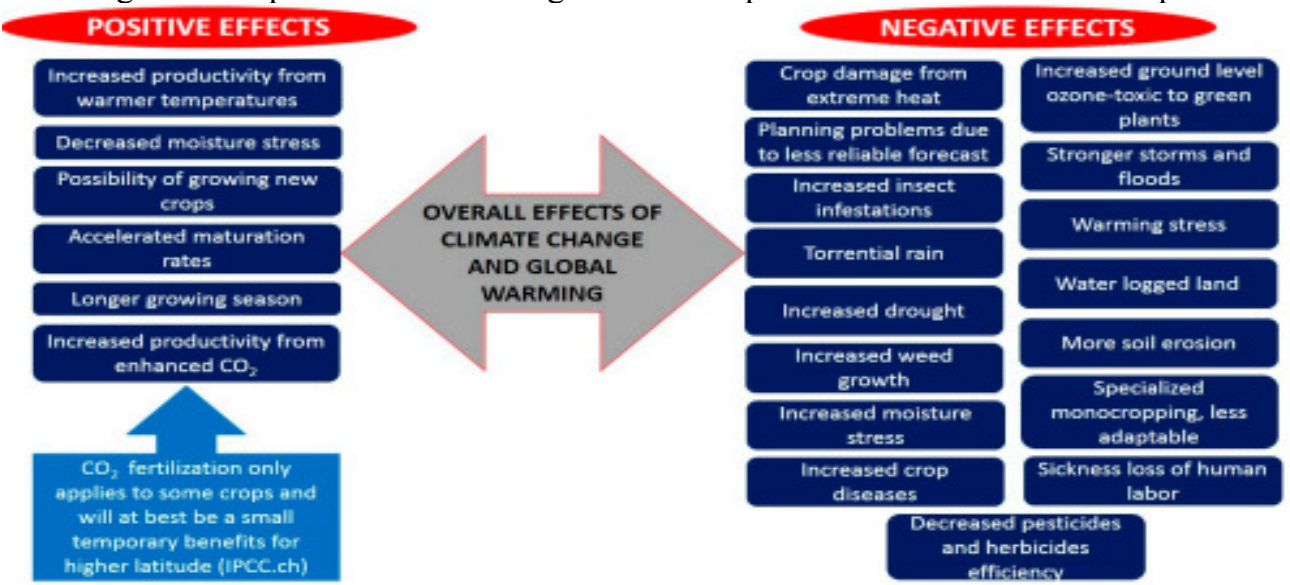

Figure 4: Overall positive and negative effects of climate change and global warming on crops and humans

\subsection{Effect of Climate Change on Livestock}

Climate change could affect livestock and dairy production. The pattern of animal husbandry may be affected by alterations in climate, cropping patterns, as well as ranges of disease vectors. The higher temperatures would likely result in a decline in dairy production, reduced animal weight gain and reproduction and lower feedconversion efficiency in warm regions. More mixed impacts are predicted for cooler regions. If the intensity and length of cold periods in temperate areas are reduced by warming, feed requirements may be reduced, survival of young animals enhanced and energy costs for heating of animal quarters reduced (Aydinalp and Cresser, 2008). Incidence of diseases of livestock and other animals are likely to be affected by climate change, since most diseases are transmitted by vectors such as ticks and flies, the development stages of which are often heavily dependent on temperature. Cattle, goat, horse and sheep are also vulnerable to an extensive range of nematode worm infections, most of which have their development stages influenced by climatic conditions. In general; intensely managed livestock systems have more potential for adaptation than mixed livestock cropping systems. Adaptation may be more problematic in pastoral systems where production is very sensitive to climate change, technology changes introduce new risks and the rate of technology adoption is slow. Livestock production may also be affected by potential changes in grain prices brought on by changing yields in some areas or by changes in rangeland and pasture productivity. For developing countries, livestock are better able to survive severe weather events such as drought than are crops and therefore a better option in terms of income protection and food security (Aydinalp and Cresser, 2008). Livestock producers can adapt to climate change by the provision of shading, sprinklers, improved air flow, lessened crowding, altered diets, and more care in handling animals. Herds or the locus of livestock production may also be moved to more hospitable locations. In the longer term, new crop varieties and livestock breeds may be developed that perform better under the anticipated future climate regime (IPCC, 1996).

\subsection{Agriculture and Climate Change Mitigation}

Regardless of the projected or actual impacts of climate change, agriculture is also likely to be directly or indirectly involved in climate change mitigation efforts. Greenhouse gas emissions (GHGE) constitute a global production externality which is likely to adversely affect climate. Actions under that convention yielded the Kyoto Protocol which represents the first significant international agreement towards GHGE reduction. Agriculture (using a definition including forestry) is mentioned as both an emitter and a sink in the protocol. Agriculture as an emission sources from enteric fermentation, manure management, rice cultivation, soil 
management, field burning and deforestation (Table 4). The protocol also lists agriculturally related sinks of afforestation and reforestation (Table 5). Additional sources and sinks are under consideration including agricultural soil carbon (McCarl et al., 2001).

Table 1: Emission and sinks sources of agriculture

\begin{tabular}{l|l}
\hline \multicolumn{2}{c}{ Agriculture is mentioned as both } \\
\hline \multicolumn{1}{c}{ Emitter } & \multicolumn{1}{c}{ Sink } \\
\hline enteric fermentation & afforestation \\
manure management & reforestation \\
rice cultivation & \\
soil management & \\
field burning & \\
deforestation & \\
\hline
\end{tabular}

Source: Aydinalp and Cresser, 2008

\subsection{Ways Agriculture would Affected by Climate Change Mitigation}

Following the arguments in McCarl and Schneider $(1999,2000 \mathrm{a})$ there are at least four ways agriculture may participate in or be influenced by greenhouse gas mitigation efforts. Agriculture may need to reduce emissions because it releases substantial amounts of methane, nitrous oxide, and carbon dioxide, agriculture may enhance its absorption of GHGE by creating or expanding sinks, agriculture may provide products which substitute for GHGE intensive products displacing emissions and agriculture may find itself operating in a world where commodity and input prices have been altered by GHGE related policies.

\subsection{General Findings on Climate Change Impact}

Several key findings have emerged across the large number of studies measuring the physiological effects of climate change on crops and to a lesser extent livestock. The effects of changes in temperature, precipitation and carbon dioxide concentrations on crop productivity have been studied extensively using crop simulation models. The combined effects of climate change have been found to have implications for dry land and irrigated crop yields as well as irrigation water use (Rosenzweig and Iglesias, 1994). IPCC (1996) noted that different crops exhibit different sensitivity. It is thus important that the full range of cropping possibilities is considered when assessing climate change. Treatment of only selected crops can bias the results. For example, early US studies only examined corn, soybeans and wheat, in contrast to later studies which included many more heat tolerant crops. The $\mathrm{CO} 2$ fertilization effect is an important factor. Inclusion of the effect in yield studies significantly raises the estimates of climate affected yields of many crops. It is however somewhat controversial (Reilly et al., 2000 b; 2001) yield effects vary latitudinally across the world. Yields generally improve in the higher latitudes. On the other hand there are estimates that there will be net reductions in crop yields in warmer, low latitude areas and semi-arid areas (Adams et al., 1998; Lewandrowski, 1999) yield changes can be reduced or enhanced by adaptations made by producers. Farmers may adapt by changing planting dates, substituting cultivars or crops, changing irrigation practices, changing land allocations to crop production, pasture and other uses (Adams et al., 1999; Kaiser et al., 1993) livestock effects can be significant.

The Environmental Protection and Research Institute sponsored (Adams et al., 1999) and recent US national assessment (Reilly et al., 2000a,b) used livestock productivity alterations ranging from -1.5 to $-5 \%$ changes in rate of gain and milk production coupled with proportional adjustments in feed and grazing requirements and reductions in input usage costs at a rate of $40 \%$ of the reduction in productivity. Irrigation water availability is an issue. Data from the US National assessment water study (Jacobs et al., 2000) were used in the parallel agricultural assessment (Reilly et al., 2000a,b) under the assumption that the same percentage change occurring in total water supply also occurred in the agricultural water supply.

\subsection{Effects of Land Use Change on ESV}

The effect of land use change on ESV was assessed when cultivated land was converted to urban areas. Land use change led to the overall decrease of ESV except for soil conservation (Table 2). Urban expansion almost resulted in the complete loss of water conservation. As a result of the increase in water conservation due to climate change, land use change totally led to the decrease of $124.03 \%$ in water conservation. The ecosystem service of nutrient cycling, gas regulation and organic production also decreased by $31.91 \%, 7.18 \%, 7.18 \%$, respectively. However, urban expansion improved soil conservation with an increase in ESV of $2.40 \%$. 
Table 2: Effects of climate and land use change on ESV in the NCP between 1988

\begin{tabular}{cccc}
\hline Ecosystem service & Actual change (\%) & Effects of climate change (\%) & Effects of land use change (\%) \\
\hline Total ecosystem service & -8.94 & 25.72 & -34.66 \\
Nutrient cycling & -3.18 & 28.73 & -31.91 \\
Water conservation & -100.00 & 24.03 & -124.03 \\
Gas regulation & 21.54 & 28.73 & -7.18 \\
Organic production & 21.54 & 28.73 & -7.18 \\
Soil conservation & -5.50 & -7.90 & 2.40 \\
\hline
\end{tabular}

Source: Chinese Academy of Sciences

Land use change significantly reduced the total ecosystem service value in the central NC decreased by $43 \%-100 \%$, while it increased the ESV in the western NCP ranging from $15 \%$ to $128 \%$ (Figure 5). Except for several regions in the northwest, all water conservation decreased by over $100 \%$ in the NCP. Soil conservation was improved in $65.28 \%$ of the counties in the NCP due to urban expansion.

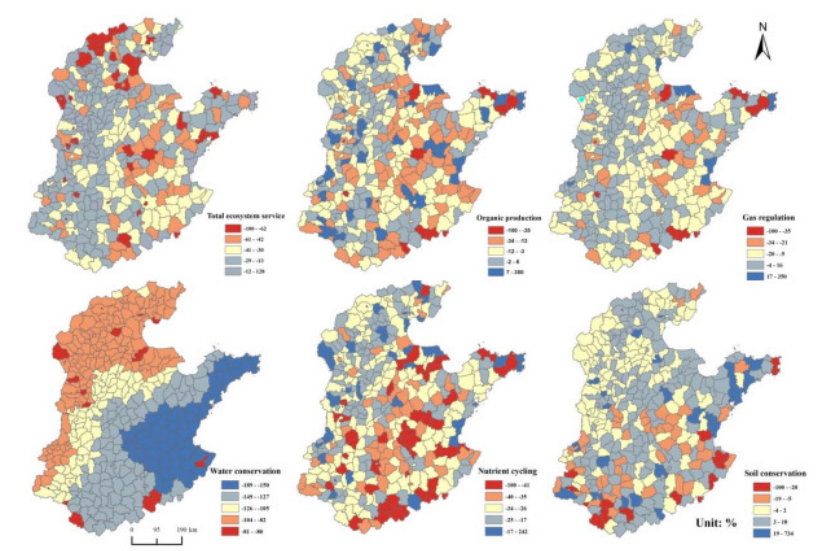

Figure 5: Percentage change in ESV induced by land use change in the NCP Source: Chinese Academy of Sciences

\subsection{Impact of Urbanization on Agriculture}

Urbanization affects all spheres of human life both in the rural and urban setting. Urbanization increased residential population and expansion of non-farm business and industry increases the pressure on farmers and makes it more costly and difficult to farm in the traditional way. The issue is complicated by the fact that population and business industry growth often takes place in prime agricultural areas (Asamoah, 2010). Urbanization has led to land use conversion from agricultural land to urban land use, such as for infrastructure, industrial, residential or commercial uses. Such land use conversion often reduces the most fertile land and therefore the impact on agricultural production and food security is often larger than the absolute amount of land involved (Francis et al., 2013).

Regmi (2014) noted that all of the future world's population growth will occur in urban areas; partially reflective of rural-urban migration trends driven by relative livelihood opportunities. He stated that approximately $35 \%$ of current urban population growth globally is attributed to rural-urban migration and in subSaharan Africa; urban population is expected to triple in the next 40 years. Growing urbanization across the globe, therefore, has important "push" and "pull" implications for agricultural research for development. Pramanik et al. (2010) noted that urbanization and population growth has serious effect on agriculture. Iheke and Nto (2010) noted that urbanization is an important driving force in migration and commuting because urban areas offer many economic opportunities to rural people through better jobs, new skills and cultural changes. Motamed et al. (2014) reported that locations with more favorable natural agriculture endowments tend to get urbanized earlier in history. Improvement in agricultural productivity is hence believed to be an important contributor to the urbanization process.

2.9.1. Expansion of urban to rural agricultural land

Land conversion is a process by which land is converted from agricultural to urban uses. Tan et al. (2009) stated that land conversion is a phenomenon that is almost inevitable during economic development and population growth periods. However, uncontrolled land conversion has greater impact on environment in general and agricultural yield in particular. Lichtenberg and Ding (2008) asserted that subsequently, some countries such as China, Japan and USA have tried to conserve agricultural land from being transformed to other uses. Higher population density, rapid economic development and the urbanization process are assumed to be the main factors 
of resulting agricultural land conversion in China. Agus and Irawan (2006) showed that, in 1995, ALC (agricultural land conversion) accounted for more than two-third of the loss in cultivated land in several areas. During 1996-2000, the rate of agricultural land conversion in the Netherlands was only 17 ha per day while in Germany in 2006 the rate was 114ha per day. Such rates are much lower than in China and Indonesia which respectively experienced 802 ha in 2004 and 514ha per day in 2000-2002. The above report makes it clear that the rate of agricultural land conversion is different in both developed and developing countries. According to Lichtenberg and Ding, 2008 there are two major drivers that contribute to agricultural land conversion; internal and external; land degradation and development and industrialization. The internal drivers land degradation is related to the location and land potential including land productivity, ownership pattern including land size and household size and income. The later includes urbanization, socio-economic conditions and government policies. The combined effects of various changes are still highly uncertain (IPCC, 2007) global land-use patterns will change in the future. Projecting their future development; it is important to study both their impacts on the earth system as well as the limitations of land use, since freshwater and fertile land is only available in limited amounts (Figure 6).

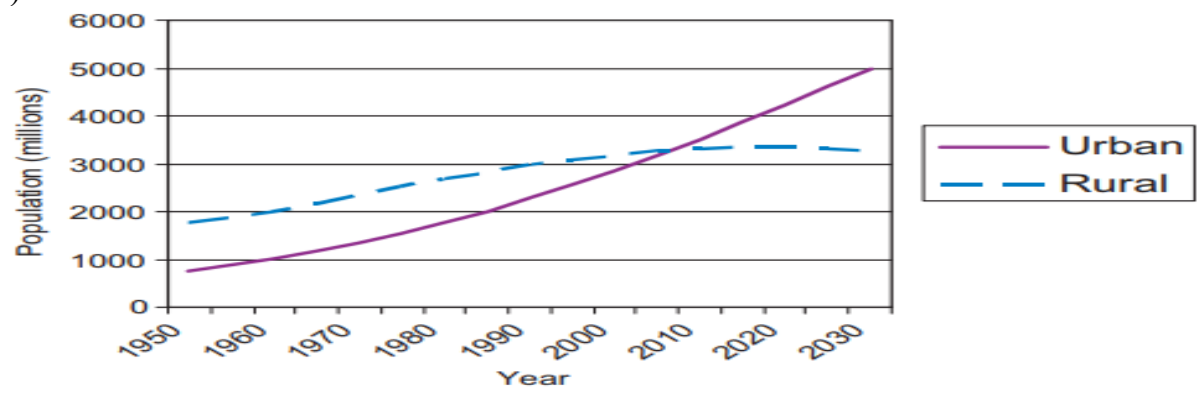

Figure 6: Estimated projected urban and rural population in the world (1950-2030).

Source: United Nations, 2002

The increase of urban population to more than 7 million would lead to a loss in agricultural land around $0.233 \mathrm{~km}^{2}$ per capita. People's migration to urban areas needs more land (Figure 7). The increase need for job, housing, recreation, commercial area, parking sites, road infrastructure, educational and other facilities that create social welfare, increases demand for land. According to Liu et al. (2008) there is a relation between economic growth and ALC.

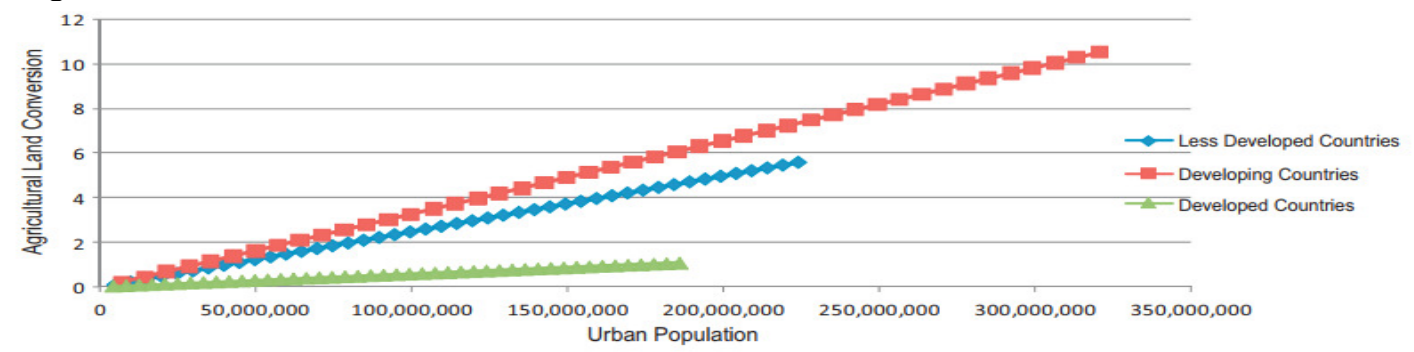

Figure 7: Estimated farmlands' loss in the three strata based on the model.

Source: Chinese Academy of Sciences

As shown in the figure below, almost for every 12-year period, developing countries have experienced the highest average of the ALC compared to less developed and developed countries (Figure 8) (Azadi et al., 2011).

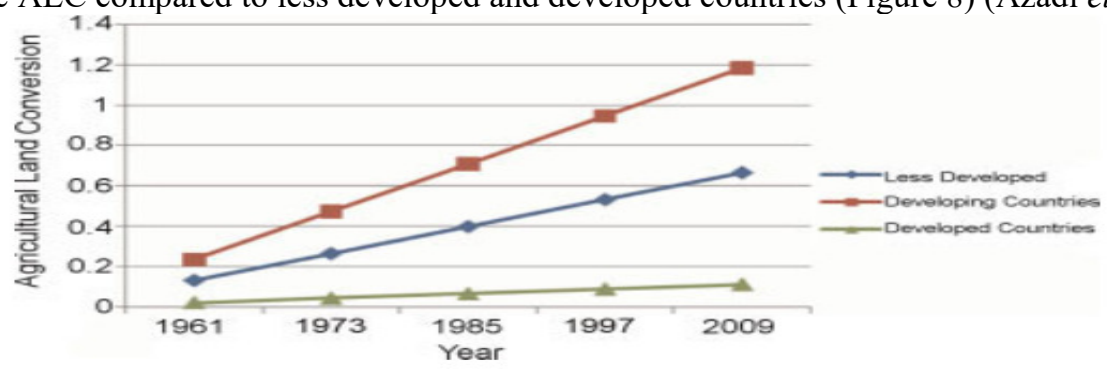

Figure 8 : The ALC trend in less developed, developing and developed countries

Source: Chinese Academy of Sciences

\subsubsection{Cultivated land loss due to urbanization in the NCP}

During the period 1986-2003, urban expansion in China occupied more than $33,400 \mathrm{~km}^{2}$ of cultivated land, accounting for $21 \%$ of total cultivated land loss (Chen, 2007) many negative effects of urbanization have been well documented, such as resource removal (Rebele, 1994) the decrease in native biodiversity (Su et al., 2011) the urban heat island effect (Arola and Korkka-Niemi, 2014) and air and water pollution (Figure 9). Many 
researchers have taken note of this, and assessed the changes in ecosystem service in response to urbanization. For example Long et al. (2014) assessed that the ecosystem service value (ESV) of the Tianjin Binhai New Areas decreased by $25.9 \%$ between 1985 and 2010 due to the conversion from ecological land to construction land.

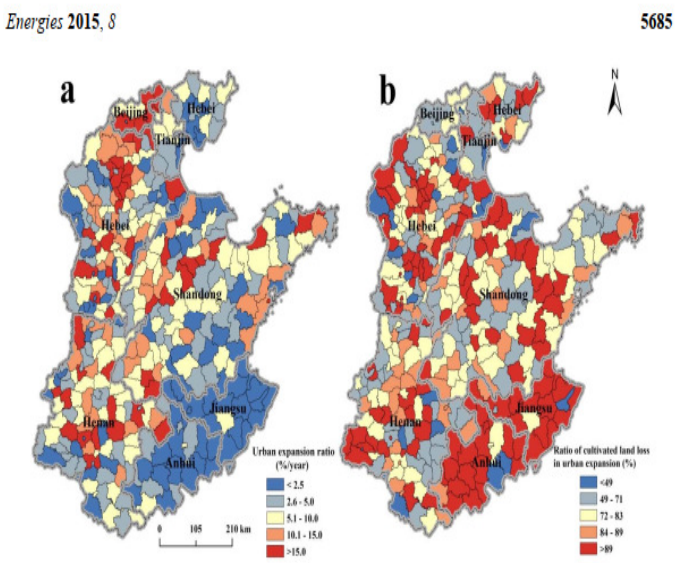

Figure 9: (a) Urban expansion rate and (b) cultivated land loss ratio in urban

Source: Chinese Academy of Sciences

In addition, about $19.89 \%$ of the expanded urban areas were converted from other construction land (i.e., rural settlement, industrial and mining land), $0.75 \%, 1.19 \%$, and $1.36 \%$ from forestry areas, grasslands and water areas, respectively. The ratio of cultivated land loss in urban expansion is higher in the southeastern NCP, ranging from $90 \%$ to $100 \%$ (Figure 9 ).

\subsection{Relationship between Climate Change and Urbanization}

The Intergovernmental Panel on Climate Change (IPCC) highlighted a need for more specific information about climate change on regional and local scales, because understanding temporal trends of climate variability is fundamental for comprehensive environmental assessments at regional and/or national scales (Baigorria et al., 2010). A shift in mean climate conditions, such as a change in temperature distributions, could lead to a corresponding change in climate extremes. Im et al.(2011) by analyzing historical data trends, observed annual mean temperatures, shows a warming trend in South Korea of $0.23^{\circ} \mathrm{c}$ per decade during the period between 1954 and 1999 and the data also indicate positive trends in both maximum and minimum temperatures for all seasons (Figure 10) (Jung et al., 2002).

Annual mean tempreture of South Korea

Figure 10: Annual mean temperature of South Korea from 1954-1999

Source: Jung et al., 2002

2.10.1. Climatic change and rural-urban migration

In particular, long-run climate change scenarios tend to suggest that extreme climate variations and more specifically, water shortage are likely to cause abrupt changes in human settlements and urbanization patterns in sub-Saharan Africa more than anywhere else in the world (Watson et al., 1998). The specific effects of climate change on rural-urban migration in sub-Saharan Africa have, however, as of date been poorly documented. A particularly important starting-point is that sub-Saharan African agriculture is especially dependent on rainfall compared to most other developing countries, which triggers the potential impact of rainfall variations on economic activity (Barrios et al., 2003).

2.10.2 The rainfall dependence of sub-Saharan African agriculture

Generally speaking, agriculture in the African tropical area is seriously hampered by high temperature, fragile soils and low yield potential. The vulnerability to rainfall in the arid and semiarid areas of the continent also translates into a poor capacity of most African soils to retain moisture. Furthermore, evapo-transpiration is in 
turn relatively high in Africa, as a consequence of high temperature throughout the year, thus leaving low quantities of water for soil moisture. The reduction of vegetative cover experienced by Africa over the past decades has also added to the insufficient inter-annual soil water storage (UNEP, 1997). Another illustration of environment-damaging agricultural practices is the intense use of fertilizer in low-quality lands. As yields increase, so will water consumption, thus creating a vicious cycle (Gommes and Petrassi, 1960). This causes greater exposure to desertification with the shortages in rainfall directly influencing agricultural productivity. This high vulnerability of agriculture on climatic conditions in turn opens the door of the possibility of largescale migrations of those whose livelihood essentially depends on rain-fed agriculture, the so-called environmental migrants that have partly converged to cities (Kelley, 1991).

\section{SUMMARY AND CONCLUSION}

There will be both winners and losers, with some areas benefiting from increases in agricultural production as a result of climate change while other areas suffer decreases in the world. The regional increases and decreases associated with climate change are not expected to result in large changes in food production over the next century on a global scale. Therefore, impacts on regional and local food supplies in some low latitude regions could amount to large percentage changes in current production. Agriculture can be affected by future climate change and current or relatively near-term efforts to mitigate climate change. In terms of projected long term climate change, the global agricultural production system appears able to continue high productivity without global threat to food security although substantial regional disturbances can occur. In terms of climate change mitigation, there is vulnerability in terms of agricultural production with mitigation efforts competing with traditional agricultural food production. Increased rate of urbanization causes loss of farm lands/decreasing size of cultivated farm lands leading increased land use intensity which in the absence of supportive technologies and inputs result to decrease in agricultural productivity. Therefore, specific areas should be earmarked for agricultural use only and protected from encroachment and other competing uses through appropriate legislations. Also, policies that will grant farmers secured right to use land should be implemented for increased productivity.

\section{REFERENCES}

Adams, R. M., B. Hurd, S. Lenhart, N. Leary, 1998. The Effects of Global Warming on Agriculture: An Interpretative Review. Journal of Climate Research 11:19-30.

Adams, R.M., B.A. Carl, K. Segerson, C. Rosenzweig, K.J. Bryant, B.L. Dixon, R. Conner, R.E. Evenson, D.Ojima, 1999. Economic Effects of Climate Change on US Agriculture. In R. Mendelsohn and J. Neumann (eds.), The Impact of Climate Change on the United States Economy. Cambridge University Press, Cambridge, pp. 18-54.

Agus F., D. Irawan, 2006. Agricultural land conversion as a threat to food security and environmental quality. Jurnal Litbang Pertanian 25: 90-98

Arola, T., K. Korkka-Niemi, 2014. The effect of urban heat islands on geothermal potential: Examples from Quaternary aquifers in Finland. Hydrogeol. J, 22:1953-1967

Asamoah, B., 2010. Urbanization and Changing Patterns of Urban Land Use in Ghana: Policy and Planning Implications for Residential Land Use in Kumasi. Unpublished MSc Dissertation, Department of Planning, KNUST.

Asseng, S., F.Ewert, P. Martre, R.P. Rötter, D. Lobell, D. Cammarano, B. Kimball, M. Ottman, G.Wall, J.W. White,2015. Rising temperatures reduce global wheat production. Nat. Clim. Change. 5:143

Aydinalp, C., M.S. Cresser, 2008. The effects of global climate change on agriculture. American-Eurasian Journal of Agricultural \& Environmental Sciences, 3(5):672-676

Azadi, H., P. Ho, L. Hasfiati, 2011. Agricultural land conversion drivers: A comparison between less developed, developing and developed countries. Land Degradation Development, 22(6):596-604.

Baigorria, G., A. Jones, J.W. GiST, 2010. A stochastic model for generating spatially and temporally correlated daily rainfall data. J. Clim. 23:5990-6008

Barnabás, B., K. Jäger, A. Fehér,2008. The effect of drought and heat stress on reproductive processes in cereals. Plant Cell Environ. 31, 11-38

Barrios S., L. Bertinelli, E. Strobl, 2003. Dry times in Africa: Rainfall and Africa's growth performance, Discussion paper 61, Center for Operations Research and Econometrics (CORE).

Bonan, G.B., S.C. Doney, 2018. Climate, ecosystems, and planetary futures: The challenge to predict life in Earth system models. Science 359

Boyer, J.S., 1982. Plant productivity and environment. Science, 218, 443-448

Bruijnzeel LA, 2004. Hydrological functions of tropical forests: Not seeing the soil for the trees. Agric. Ecosys. Environ. 104(1):185-228

CAST, 2001. Council for Agricultural Science and Technology Forthcoming report on Climate Change and Climate Change Mitigation, Ames, Iowa, USA, CAST 
Chen, J, 2007. Rapid urbanization in China: A real challenge to soil protection and food security. Catena, 69:115

Espeland, E.K., K.M Kettenring, 2018. Strategic plant choices can alleviate climate change impacts: A review. $J$. Environ. Manag. 222: 316-324

Foley, J.A., R. DeFries, G.P. Asner, C. Barford, G. Bonan, 2005. Global consequences of land use. Science 309: 570-574

Francis, Z.N., R.D. Dinye, R.K. Kasanga, 2013. Urbanization and its Impact On Agricultural Lands in Growing Cities in Developing Countries: A Case Study Of Tamale In Ghana. Modern Social Science Journal, 2 (2): 256-287

Gommes R., F. Petrassi, 1960. Rainfall variability and drought in sub-Saharan Africa, FAO Agrometeorology Series 9 (1996)

Gregory, P.J., J.S.I. Ingram, M. Brklacich, 2005. Climate change and food security. Philos. Trans. R Soc. London B Biol. Sci. 29:360(1463):2139-2148

Griffin, J.J., T.G. Ranney, D.M. Pharr, 2004. Heat and drought influence photosynthesis, water relations, and soluble carbohydrates of two ecotypes of redbud (Cercis canadensis). J. Am. Soc. Hortic. Sci.129, 497-502

Hope, K.R., 2009. Climate change and poverty in Africa. Int J Sust Devel World Ecol 16: 451-461

Iheke, O. R, P.O. Nto, 2010. Effect of Population Pressure/Urbanization on the Adoption of Sustainable Agricultural Practices by Farmers: a Case Study of South Eastern Nigeria. Journal of Food and Fibre Production 3(1): 543-549

Im, E.S.; Jung, I.W.; Bae, D.H, 2011. The temporal and spatial structures of recent and future trends in extreme indices over Korea from a regional climate projection. Int. J. Climatol., 31:72-86

IPCC, 1990. First Assessment Report 1990 (FAR), http://www.ipcc.ch/publications and data/publications and data reports.shtml

IPCC, 1996. Climate Change 1995: The IPCC Second Assessment Report, Scientific-Technical Analyses of Impacts, Adaptations, and Mitigation of Climate Change, Watson, R.T., M.C. Zinyowera, and R.H. Moss (eds.). Cambridge University Press: Cambridge and New York

IPCC, 2007. Summary for Policymakers. In Climate Change 2007, published for the Inter governmental Panel on Climate Change. Cambridge University Press. Cambridge. pp 2-18

Jacobs, K., D.B. Adams, P. Gleick, 2000. Potential Consequences of Climate Variability and Change for the Water Resources of the United States in US Global Climate Change Program National Assessment Report The Potential Consequences of Climate Variability and Change available

Jung, S.H., Y.E. Choi, J.H. Oh, G.H. Lim, 2002. Recent trends in temperature and precipitation over South Korea. Int. J. Climatol., 22:1327-1337

Kaiser, H.M. S.J. Riha, D.S.Wilks, D.G. Rossier, R. Sampath, 1993. A Farm-Level Analysis of Economic and Agronomic Impacts of Gradual Warming. American Journal of Agricultural Economics 75:387-398

Kalnay,E.,Cai,M.,2003.Impact of urbanization and land-use change on climate.Nature 423:528-529

Kelley, A., 1991. African urbanization and city growth: Perspectives, problems, and policies. Unpublished manuscript, Duke University

Klein,T., Holzkämper,A., Calanca,P., Fuhrer,J., 2013. Adaptation options under climate change for multifunctional agriculture: A simulation study for western Switzerland, Reg. Env. Change, article in press

Lewandrowski J, and D, Schimmel pfennig, 1999. Economic Implications of Climate Change for US Agriculture: Assessing Recent Evidence. Land Economics 75: 39-57

Lichtenberg, E., C.Ding, 2008. Assessing farmland protection policy in China. Land Use Policy 25:59-68

Liu, L.J., M. Song, H. Yokogawa, B.X. Qu, 2008. Exploring the environmental kuznets curve hypothesis between economic growth and farmland conversion in China. Journal of the Faculty of Agriculture 53: 321327

Long, H.L., Y.Q. Liu, X.G. Hou, T.T. Li, Y.R. Li, , 2014. Effects of land use transitions due to rapid urbanization on ecosystem services: Implications for urban planning in the new developing area of China. Habitat Int, 44:536-544

McCarl, B. A. and J. M. Reilly, 1999. Water and the Agricultural Climate Change Assessment: Issues from the Standpoint of Agricultural Economists, Proceedings of American Water Resources Association Special Conference on Potential Consequences of Climate Variability and Change to Water Resources, Atlanta, GA.

McCarl, B.A. and U. Schneider, 2000a. Agriculture's Role in a Greenhouse Gas Emission Mitigation World: An Economic Perspective. Review of Agricultural Economics, 22(1):134-159

McCarl, B.A., Adams, R.M., Hurd, B.H, 2001. Global climate change and its impact on agriculture. Encyclopedia of life support systems. Institute of Economics Academia Sinica, and UNESCO. Retrieved from http://agecon2. tamu. edu/people/faculty/mccarl-bruce/papers/879.

McCarl, B.A., U.Schneider, 1999. Curbing Greenhouse Gases: Agriculture's Role.Choices, First Quarter, 9-12.

Motamed, M.J., Florax, R. J. G. M. \& Masters, W. A, 2014. Agriculture, Transportation and the Timing of 
Urbanization: Global Analysis at the Grid Cell Level. (Working Paper, TI Discussion Paper, no 14002/VIII). Amsterdam: Tinbergen Institute.

Muller C, Cramer W, Hare WL, Lotze-Campen H, 2011. Climate change risks for African agriculture. Proc Natl Acad Sci USA 108: 4313-4315

Oke TR, 1981. Canyon geometry and the nocturnal urban heat island: comparison of scale model and field observations. J Climatol 1: 237-254

Parry, M.L., 2007. Impacts, Adaptation and Vulnerability. Contribution of Working Group II to the Fourth Assessment Report of the Intergovernmental Panel on Climate Change, Cambridge University Press, Cambridge, United Kingdom.

Pereira, A., 2016. Plant abiotic stress challenges from the changing environment. Front.Plant Sci, 7:11-23

Pielke RA, 2005. Land use and climate change. Science 310: 1625-1626

Pielke RA, Marland G, Betts RA, Chase TN, Eastman JL, 2002. The influence of land-use change and landscape dynamics on the climate system:

Pramanik C., Dey, S. K. and Sarkar, A, 2010. Effect of Urbanization on Agriculture: A Special Scenario on Andhra Pradesh, Indian International Journal of Applied Science and Computations, 17(2):121-128

Rebele, F, 1994. Urban ecology and special features of urban ecosystems. Global Ecol. Biogeogr, 4:173-187

Regmi, A, 2014. The push-pull effects of urbanization on agriculture. Paper Presented at the Reviving dry lands dialogue: bridging policy and research; CGIAR Consortium, held at the African Studies Centre, Netherlands

Reilly,J.M., J. Graham, D.G. Abler, R.Darwin, S. Hollinger, C. Izaurralde, S. Jagtap, J.Jones, J. Kimble, B.A.McCarl, L.Mearns, D.Ojima, E.A. Paul, K. Paustian, S. Riha, N. Rosenberg, C. Rosenzweig, and F. Tubiello, 2000b. Report of the Agricultural Sector Assessment Team, US Global Change Research Program National Assessment Report on Changing Climate and Changing agriculture

Rosenzweig, C. and A. Iglesias (eds), 1994. Implications of Climate Change for International Agriculture: Crop Modeling Study. EPA 230-B-94-003

Saini, H., D.Aspinall,1982. Abnormal sporogenesis in wheat (Triticum aestivum L.) induced by short periods of high temperature. Ann. Bot. 49:835-846

Sala OE, Chapin S, Armesto JJ, Berlow E, Bloomfield J, 2000. Global biodiversity scenarios for the year, Science 287: 1770-1774

Salehi-Lisar, S.Y., H. Bakhshayeshan-Agdam,2016. Drought stress in plants: Causes, consequences, and tolerance. In Drought Stress Tolerance in Plants; Springer: Berlin/Heidelberg, Germany, 1:1-16

Sanchez PA, 2000. Linking climate change research with food security and poverty reduction in the tropics Agriculture, Econ, Environ. 82(1-3):371-383

Scheben, A., Y. Yuan, D. Edwards, 2016. Advances in genomics for adapting crops to climate change. Curr. Plant Biol.6: 2-10

Sheoran, I.S., H.S Saini,1996. Drought-induced male sterility in rice: Changes in carbohydrate levels and enzyme activities associated with the inhibition of starch accumulation in pollen. Sex. Plant Reprod. 9: 161169

Siwar C, Ahmed F, Begum RA, 2013. Climate change, agriculture and food security issues: Malaysian perspective. J. Food Agric. Environ. 11(2):1118-1123

Su, Z.M.; Zhang,R.Z.; Qiu, J.X, 2011. Decline in the diversity of willow trunk-dwelling weevils (Coleoptera curculionoidea) as a result of urban expansion in Beijing, China. J. Insect. Conserv, 15:367-377

Tan R, Beckmann V, Van den Berg L, Qu F, 2009. Governing farmland conversion: Comparing China with the Netherlands and Germany. Land Use Policy 26: 961-974

Thornton, P.K.; Ericksen, P.J.; Herrero, M.; A.J. Challinor, 2014. Climate variability and vulnerability to climate change: A review. Glob. Chang. Biol. 20, 3313-3328.

UNEP,1997. World Atlas of Desertification, United Nations Environment Program, Edward Arnold, London

Van ,V.H., 2007. Mapping Biophysical Factors That Influence Agricultural Production and Rural Vulnerability; Food \& Agriculture Organization: Rome, Italy

Walker B, Steffen W, 1997. An overview of the implications of global change for natural and managed terrestrial ecosystems, Cons. Ecol. 1(2):2

Watson, R.T. M.C. Zinyowera, R.H. Moss, D.J. Dokken, 1998. The Regional Impacts of Climate Change. An Assessment of Vulnerability, Special Report of IPCC Working Group II, Cambridge Univ. Press.

Winkel, T., J.F. Renno, W. Payne,1997. Effect of the timing of water deficit on growth, phenology and yield of pearl millet (Pennisetum glaucum (L.) R. Br.) grown in Sahelian conditions. J. Exp. Bot. 48, 1001-1009

World Bank, 2000. World Development Report 1999/2000. Entering the $21^{\text {st }}$ Century. New York, World Bank.

WRI, 1998. World Resources 1998/99. A joint publication by The World Resources Institute. The United Nations Development Programme, The United Nations Environment Programmers and The World Bank New York, Oxford University Press. 
Zandalinas, S.I., R. Mittler, D. Balfagón, V. Arbona, A. Gómez-Cadenas,2018. Plant adaptations to the combination of drought and high temperatures. Physiol. Plant.162: 2-12

Zhao, C. B. Liu, S. Piao, X. Wang, D.B. Lobell, Y. Huang, M. Huang, Y. Yao, S. Bassu, P. Ciais, 2017. Temperature increase reduces global yields of major crops in four independent estimates. Proc. Natl. Acad. Sci. USA, 114: 9326-9331

Zhou X, Wang YC, 2011. Dynamics of land surface temperature in response to land use/cover change. Geogr Res 49: 23-26 